\title{
The Effects of Extending Unemployment Insurance Benefits
}

\author{
Maria Canon, Economist \\ Yang Liu, Senior Research Associate
}

$\mathbf{T}$ he Emergency Unemployment Compensation (EUC) program took effect after passage of the Unemployment Extension Act on November 21, 2008, in the wake of the surging U.S. unemployment rate. ${ }^{1}$ The program provided additional weeks of unemployment insurance (UI) benefits to long-term unemployed workers and guaranteed a minimum living standard. As the U.S. economy recovered and the unemployment rate declined, policymakers allowed the EUC program to expire at the end of 2013, leaving the maximum length of unemployment benefits at 46 weeks. ${ }^{2}$ However, the program's expiration remains a topic for debate.

Supporters of extended benefits argue that they provided an important resource for long-term unemployed workers to continue searching for jobs. Other researchers claim that such an extension is ineffective in raising employment: Longer benefits may reduce unemployed workers' job search efforts and raise their reservation wage, decreasing their likelihood of becoming reemployed. Extended benefits may also encourage unemployed workers to remain in the labor force to collect benefits, when they may have exited the labor force completely otherwise. Both these channels increase the unemployment rate in the short term.

Rothstein (2011) and Farber and Valletta (2013) found that extended benefits slightly reduced the probability that eligible unemployed workers would exit the labor force. Rothstein's analysis found the extension increased the unemployment rate by 0.1 to 0.5 percentage points in early 2011. Farber and Valletta (2013) found that the extension increased the unemployment rate by about 0.4 percentage points between 2009 and 2011.

To understand the effects of the actual EUC expiration in December 2013, we compute (counterfactual) unemployment rates as if the extended benefits had expired earlierin September 2013, October 2013, or November 2013. We compare the behavior of workers whose UI benefits were ending (after 39 weeks) in 2008 with the behavior of workers whose UI benefits were ending (after 46 weeks) in 2013, when the EUC program expired. Specifically, we studied the probabilities these workers would change their labor status - that is, become employed, continue to be unemployed, or exit the labor force. Our assumption is that workers facing a loss of benefits in 2013 would have adjusted their job search intensity the same way workers did in 2008. (We keep economic conditions consistent, as observed in 2013.) We then use these adjusted transition probabilities to compute the counterfactual unemployment rates, which we compare with the actual unemployment rate.

\section{Longer benefits may reduce unemployed workers' job search efforts, decreasing their likelihood of becoming reemployed.}

The first table shows that, had the EUC program expired earlier in 2013, workers with 46 or more weeks of continuous unemployment would have been 1.2 to 2.1 percentage points more likely to move from unemployment to reemployment: Workers would have increased their search intensity, and more unemployed workers would have found and/or accepted jobs. Similarly, the long-term unemployed would have been 0.4 to 0.5 percentage points more likely to exit the labor force entirely. The increases in these two probabilities result in a drop of 1.7 to 2.5 percentage points in the probability these workers would remain unemployed.

How do these transition probabilities affect the unemployment rate? The unemployment rate is the ratio of unemployed workers to the labor force (unemployed workers looking for a job plus employed workers). Higher employment rates decrease unemployment. However, higher rates of unemployed workers leaving the labor force might increase (through a smaller labor force) or 


\section{Labor Force Status Transition*}

\begin{tabular}{|c|c|c|c|c|c|c|}
\hline \multirow[b]{2}{*}{ Month } & \multicolumn{3}{|c|}{ Actual transition probability (\%) } & \multicolumn{3}{|c|}{ Adjusted transition probability (\%) } \\
\hline & Reemployed & Exit labor force & Remain unemployed & Reemployed & Exit labor force & Remain unemployed \\
\hline September 2013 & 14.28 & 22.66 & 63.06 & 16.37 & 23.05 & 60.59 \\
\hline November 2013 & 8.84 & 27.89 & 63.27 & 10.14 & 28.36 & 61.50 \\
\hline December 2013 & 8.47 & 28.33 & 63.19 & 9.71 & 28.82 & 61.47 \\
\hline
\end{tabular}

NOTE: *Probabilities are for workers unemployed 46 weeks or longer.

SOURCE: Current Population Survey, U.S. Census Bureau.

decrease (through fewer unemployed workers) the unemployment rate. The final result depends on which effect dominates.

The second table shows that if the EUC program had expired early, the unemployment rate would have been 0.03 to 0.05 percentage points lower in late 2013 than the observed unemployment rate. ${ }^{3}$ These results are generally in line with those in Rothstein (2011) and Farber and Valletta (2013). Because the ratio of longer-term unemployment to total unemployment declined significantly between 2011 and 2013, the scale of the effect is much smaller than that observed by Rothstein (2011) and Farber and Valletta (2013) using 2009-11 data.

In summary, we find that the extension of unemployment benefits affected the labor market status of long-term unemployed workers in late 2013. Without extended UI benefits, these unemployed workers would have been more likely to be employed, more likely to exit the labor force, and on average 1.9 percent less likely to remain unemployed in the following period. In short, our simulated early termination of the EUC program lowered the unemployment rate by 3 to 5 basis points, suggesting that the December 2013 expiration of the EUC program might have slightly lowered the unemployment rate in early 2014.

\section{NOTES}

${ }^{1}$ Every recession back to 1950 has included a temporary emergency federal benefit program. The 2008 EUC program is the main benefits program for the 2008-09 recession;

http://www.workforcesecurity.doleta.gov/unemploy/pdf/euc08.pdf.

2 Before November 21, 2008, eligible workers in most states could receive 26 weeks of regular and 13 weeks of extended benefits ( 39 weeks). As of January 2014 , they can receive 26 weeks of regular and 20 weeks of extended benefits (46 weeks).

\section{Observed and Simulated Unemployment Rate}

\begin{tabular}{lcc} 
Month & $\begin{array}{c}\text { Simulated } \\
\text { unemployment } \\
\text { rate (\%) }\end{array}$ & $\begin{array}{c}\text { Observed } \\
\text { unemployment } \\
\text { rate (\%) }\end{array}$ \\
\hline September 2008 & & 5.71 \\
October 2008 & & 5.97 \\
November 2008 & & 6.19 \\
December 2008 & 6.78 & 6.92 \\
September 2013 & 6.83 & 6.83 \\
October 2013 & 6.39 & 6.86 \\
November 2013 & 6.42 & 6.42 \\
December 2013 & & 6.46
\end{tabular}

SOURCE: Current Population Survey, U.S. Census Bureau.

\begin{abstract}
3 The observed unemployment rate is calculated as the number of employed workers divided by the total labor force ( 16 to 64 years of age) based on Current Population Survey data and does not exactly match the BLS unemployment rate.
\end{abstract}

\section{REFERENCES}

Farber, Henry S. and Valletta, Robert G. “Do Extended Unemployment Benefits Lengthen Unemployment Spells? Evidence from Recent Cycles in the U.S. Labor Market." Federal Reserve Bank of San Francisco Working Paper No. 2013-09, April 2013; http://www.frbsf.org/economic-research/files/wp2013-09.pdf.

Rothstein, Jesse. "Unemployment Insurance and Job Search in the Great Recession." Brookings Papers on Economic Activity, Fall 2011, pp. 143-210; http://www.brookings.edu/about/projects/bpea/editions/ /media/Projects/ BPEA/Fall\%202011/2011b_bpea_rothstein.PDF. 